\title{
Embryo sac formation and early embryo development in Agave tequilana (Asparagaceae)
}

\author{
Alejandra G González-Gutiérrez, Antonia Gutiérrez-Mora and Benjamín Rodríguez-Garay*
}

\begin{abstract}
Agave tequilana is an angiosperm species that belongs to the family Asparagaceae (formerly Agavaceae). Even though there is information regarding to some aspects related to the megagametogenesis of $A$. tequilana, this is the first report describing the complete process of megasporogenesis, megagametogenesis, the early embryo and endosperm development process in detail. The objective of this work was to study and characterize all the above processes and the distinctive morphological changes of the micropylar and chalazal extremes after fertilization in this species. The agave plant material for the present study was collected from commercial plantations in the state of Jalisco, Mexico. Ovules and immature seeds, previously fixed in FAA and kept in ethanol 70\%, were stained based on a tissue clarification technique by using a Mayer's-Hematoxylin solution. The tissue clarification technique was successfully used for the characterization of the megasporogenesis, megagametogenesis, mature embryo sac formation, the early embryo and endosperm development processes by studying intact cells. The embryo sac of $A$. tequilana was confirmed to be of the monosporic Polygonum-type and an helobial endosperm formation. Also, the time-lapse of the developmental processes studied was recorded.
\end{abstract}

Keywords: Agavaceae; Chalazal haustorium; Helobial endosperm; Hypostase; Megagametogenesis; Megasporogenesis; Polygonum-type

\section{Background}

One of the main characteristics of Angiosperms is that they possess seeds enclosed inside a fruit derived from the ovary of flowers (Li and Ma 2002). Another outstanding characteristic of angiosperms is that they present alternation of generations in their life cycle (as in many other plants), that is divided in two phases: one dominant diploid phase, which is called sporophytic, and one haploid phase known as gametophytic (Haig 1990; RodríguezGaray et al. 2000; Fan et al. 2008; Ma and Sundaresan 2010). The main function of the gametophyte phase is the production of haploid gametes whether they are male or female (Reiser and Fischer 1993; Yadegari and Drews 2004; Fan et al. 2008).

The female gametophyte, also named megagametophyte or embryo sac, is developed within the carpel, which consists of three elements: the stigma, the style and the ovary, which can contain one or several ovules (Gutiérrez-Mora

\footnotetext{
*Correspondence: brodriguez@ciatej.mx

Unidad de Biotecnología Vegetal, Centro de Investigación y Asistencia en Tecnología y Diseño del Estado de Jalisco, A.C. (CIATEJ), Av. Normalistas No. 800, Col. Colinas de la Normal, Guadalajara, Jalisco 44270, México
}

et al. 2012). In each ovule meiosis of the megaspore mother cell produces four haploid cells called megaspores. In the monosporic pattern, three of these megaspores degenerate while the closest cell to the chalazal region remains viable and gives rise to a single functional megaspore.

During the megagametogenesis process, the functional megaspore passes through one or more mitotic divisions without cytokinesis forming a multinucleate coenocyte. Latter, cell walls are formed around the nuclei resulting in a mature embryo sac (Rabiger and Drews 2013). The embryo sacs may present a diversity of developmental pathways, however, the most common is the monosporic Polygonum-type, in which the functional megaspore passes through three mitotic divisions producing a seven celled embryo sac (Chasan and Walbot 1993; Li and Ma 2002; Maheshwari 1937) consisting of three antipodal cells, one central cell formed by two polar nuclei, two synergid cells, and the egg cell (Dresselhaus 2006; Kägi and Groß-Hardt 2007; Yang et al. 2010).

Some studies have characterized the female gametophyte of different species belonging to the Asparagaceae

\section{穴}


family formerly Agavaceae (APG III 2009), where the majority of them have been described as Monosporic Polygonum-type. Among these species, Yucca rupicola (Watkins 1937); Y. aloifolia (Wolf 1940); Y. filamentosa (Reed 1903); Agave lechuguilla (Grove 1941), A. virginica (Regen 1941), Hesperocallis undulata, Leucocrinum montanum (Cave 1948) and Comospermum yedoense (Rudall 1999) are found. However, Piven et al. (2001) reported the embryo sac development of Agave fourcroydes and $A$. angustifolia as bisporic Allium-type.

Only one study could be found that was centered on the Agave tequilana female gametophyte development where Escobar-Guzmán et al. (2008) reported that the megagametophyte is originated from the megaspore that is located closest to the chalazal region, forming an embryo sac of seven cells (Polygonum-type). However, these authors did not report or describe the whole mitotic division process that gives rise to this sac with seven cells, nor the early embryogenesis. Even though there is information regarding to some aspects related to the megagametogenesis of $A$. tequilana, there is no published information describing the embryo and endosperm development in this species and the distinctive morphological changes of the embryo sac after fertilization.

The objective of this work was to study and characterize the process of megasporogenesis, megagametogenesis, the mature embryo sac formation and the early embryo development in Agave tequilana Weber which is the raw material for the production of Tequila in Mexico, in order to get basic knowledge useful for plant systematics and evolution studies and plant breeding programs, which may include in vitro fertilization and the production of haploid plants among others.

\section{Results}

A total of 5,000 ovules were taken from floral buds at diverse stages, receptive flowers and immature fruits were analyzed. Different developmental stages of the collected ovules were studied from megasporogenesis to the first division of the embryo. The plant material used in this study consisted of inflorescences collected from May to June in the years 2010-2013 (Figure 1). It was difficult to know the specific timeframe of each developmental stage of the embryo sac, however, it could be observed that it takes about 15 days for the floral buds since their appearance to reach the maturity of the embryo sac.

\section{Megasporogenesis}

The process of megasporogenesis was observed using ovules in different developmental stages. The first observed stages showed a megaspore mother cell (MMC) differentiation from the nucellar tissue (Figure 2a). This MMC goes through a meiotic cell division that first results in a dyad and finally in a linear tetrad of haploid cells with a chalaza-micropylar orientation (Figure 2b, c), the average size of the tetrad is about $58 \mu \mathrm{m}$ long and $21 \mu \mathrm{m}$ wide (for the rest of measurements mentioned on this paper see Additional file 1: Table S1).

Once the meiotic tetrad is formed, the three megaspores closest to the micropylar pole degenerate (Figure $2 \mathrm{~d}$ ) and their remains could be observed as highly stained spots which were frequently observed in the two-nucleated embryo sacs. Only the megaspore cell closest to the chalazal pole remains viable, becoming the functional megaspore (FM), and its size is bigger than the rest of the cells in the tetrad with dimensions of about $33 \mu \mathrm{m}$ long and $23 \mu \mathrm{m}$ wide.

\section{Megagametogenesis}

The process of megagametogenesis starts with the increase in size of the FM, which is about $43 \mu \mathrm{m}$ long and $25 \mu \mathrm{m}$ wide. At this stage, the hypostase starts to be visible just above the FM in the nucellar tissue; this structure was detected as a well defined and intensely stained group of cells, which have a poor cytoplasmic content and thickened cell walls (Figure 3a) (also see Additional file 2: Figure S1).

The first mitotic division of the functional megaspore produces two nuclei, one located at the chalazal pole and the other one at the micropylar pole, both separated by a large vacuole in the center of the embryo sac without cytokinesis. At this stage, the mean size of the embryo sac is about $50 \mu \mathrm{m}$ long and $35 \mu \mathrm{m}$ wide (Figure $3 \mathrm{~b}$ ). Later, these two nuclei divided again forming four nuclei, two located at the chalazal end and the other two at the micropylar end of the embryo sac (Figure 3c). At the same time, the embryo sac continues expanding its size to about $60 \mu \mathrm{m}$ long and $42 \mu \mathrm{m}$ wide, and in both stages of embryo sac development its morphology is ovoid. A third and last mitotic division gives place to an eight-nucleated embryo sac (Figure 3d). These three mitotic divisions occur in a synchronized manner at both extremes of the embryo sac.

\section{The mature embryo sac}

The study of mature embryo sacs was carried out in ovules from flowers with mature and receptive stigma. At the mature stage, the size of the embryo sacs is about $247 \mu \mathrm{m}$ long and $106 \mu \mathrm{m}$ wide and they are wider at the chalazal pole than at the micropylar end, having a bulbous form with a small and narrow haustorial tube at the chalazal end which connects to the hypostase (Figure 4a). At this stage, the embryo sac is already cellularized and consists of seven cells: three antipodal cells situated at the chalazal haustorium, which degenerate rapidly (frequently only their residues in the form of three highly stained spots could be observed, however, also nondegenerated antipodal cells could be observed); the central cell formed by two polar nuclei was observed just below the antipodals and they were beside each other, 

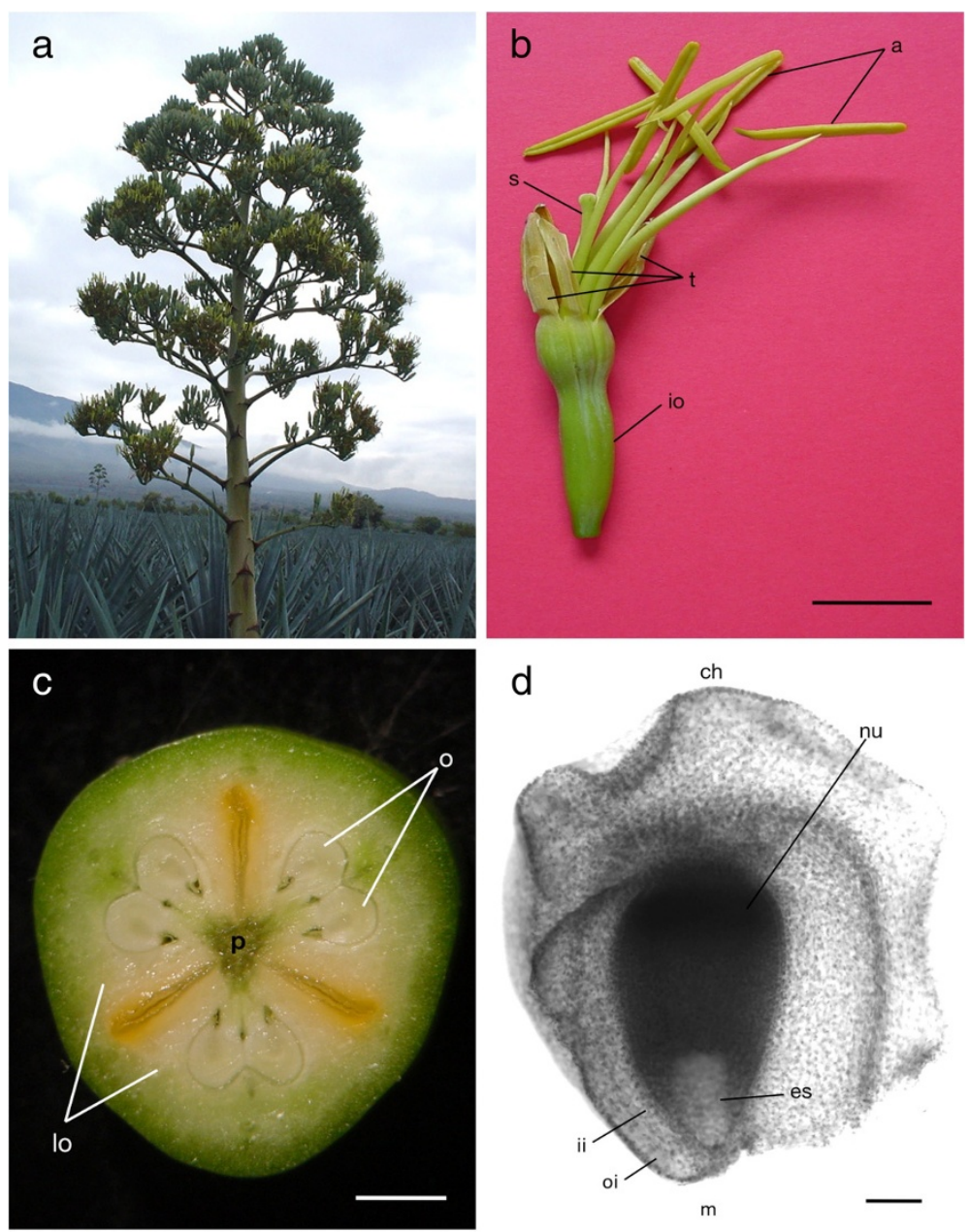

Figure 1 Plant material of Agave tequilana Weber for the present study. a) Commercial plantation in the state of Jalisco, México. b) Hermafrodite agave flower. $\mathrm{Bar}=1 \mathrm{~cm}$. c) Agave ovary components. Bar $=2 \mathrm{~mm}$. d) Agave immature ovule. $\mathrm{Bar}=50 \mu \mathrm{m} . \mathrm{a}=\mathrm{anthers,} \mathrm{t}=$ tepals, io = inferous ovary, $\mathrm{s}=$ style, $\mathrm{o}=$ ovules, $\mathrm{lo}=$ locules, $\mathrm{p}=$ placentae, $\mathrm{ch}=$ chalaza, $\mathrm{m}=$ micropyle, $\mathrm{i}=$ interior integument, $\mathrm{o}=$ outer integument, $\mathrm{n}=$ nucellar tissue, es = embryo sac.

being very similar in shape and size (Figure $4 \mathrm{~b})$ (also see Additional file 2: Figures S2 and S4). Finally, the egg apparatus composed of one egg cell and two synergids was observed at the micropylar end (Figure 4a, b and c).

\section{Egg apparatus}

Both synergids were found located at the micropylar end next to each other and generally observed in the same focal plane, while the egg cell was usually in a different focal plane and positioned between the two synergids. These three cells composing the ovular apparatus of Agave tequilana had their walls in contact with the micropylar edge of the female gametophyte (Figure 4d). The synergids are very similar to each other, and each cell possesses a vacuole polarized towards the chalazal end and the nucleus polarized towards the micropylar end (see Aditional file 2: Figure S3). The egg cells showed diverse morphologies probably due to different developmental stages at the moment of observation, however, in general, they had a highly dense nucleus located towards the chalazal extreme and a large vacuole occupying almost the whole space of the cell located towards the micropylar end of the sac with a size of about $28 \mu \mathrm{m}$ long and $23 \mu \mathrm{m}$ wide (Figure 5).

\section{The central cell: karyogamy of the polar nuclei}

At the second day after pollination, the analyzed ovules did not show any change in size or morphology; however, the fusion of the two polar nuclei (karyogamy) to form the nucleus of the central cell was observed. This karyogamy in Agave tequilana occurs before the process of double fertilization (Figure 4c). The central cell nucleus remained located at the same position where both polar nuclei were observed at the chalazal extreme of the embryo sac. The central cell nucleus showed semicircular to ovate morphologies with an approximate size 

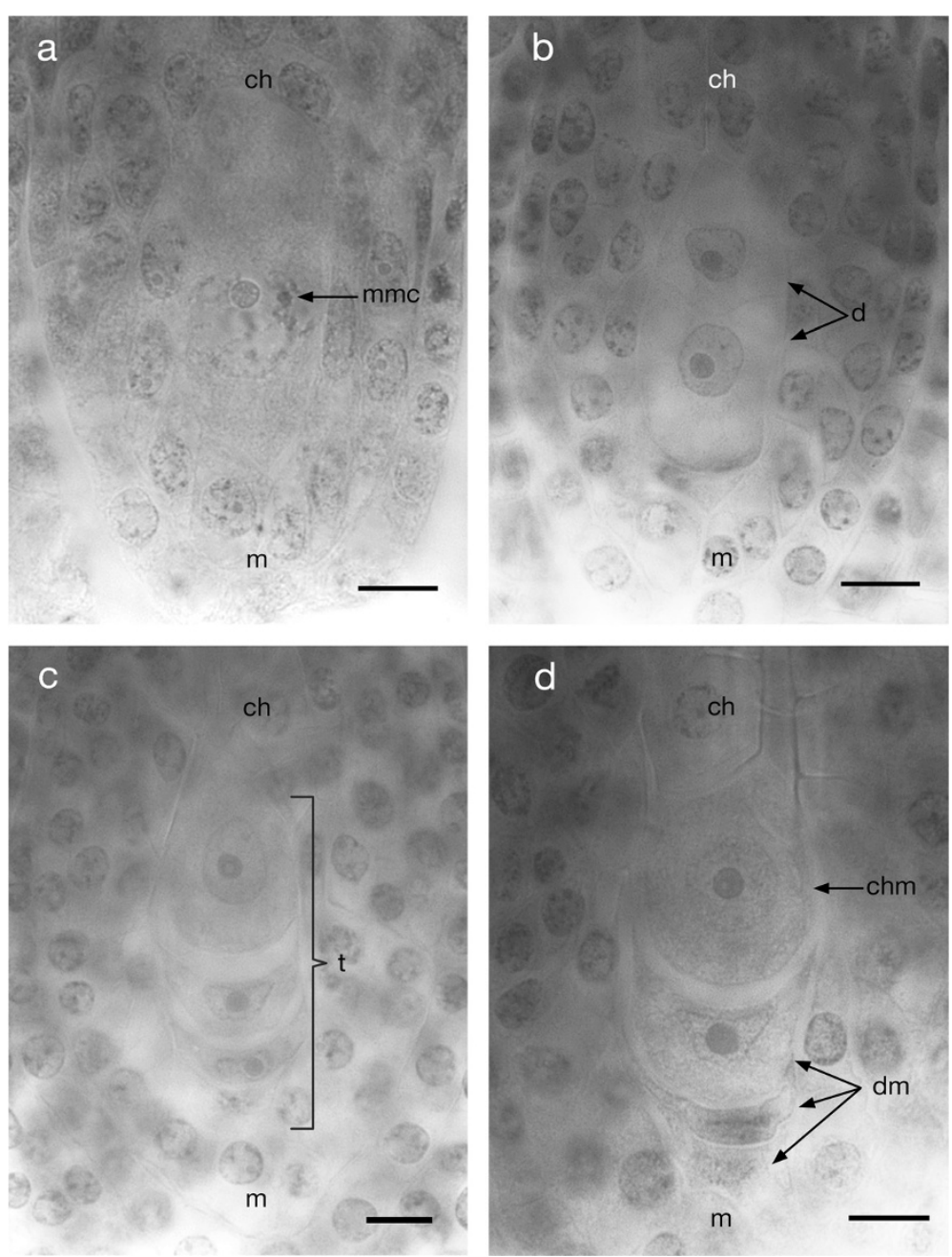

Figure 2 Megasporogenesis of Agave tequilana Weber. a) Diploid megaspore mother cell. b) Diad after the first meiotic division formed by two haploid cells. c) Tetrad after the second meiotic division composed by four haploid cells. d) Three degenerating megaspores and one intact functional megaspore located at the chalazal pole of the future embryo sac. $c h=$ chalaza, $m=$ micropyle, $m m c=$ megaspore mother cell, $d=$ dyad, $\mathrm{t}=$ tetrad, $\mathrm{chm}=$ chalazal megaspore, $\mathrm{dm}=$ degenerating megaspores. Bars $=10 \mu \mathrm{m}$.

of $17 \mu \mathrm{m}$ long and $13 \mu \mathrm{m}$ wide, and the approximate distance between the nucleus of the egg cell and that of the central cell was $210 \mu \mathrm{m}$.

\section{Endosperm and zygote formation}

After the double fertilization took place at three DAP (to be published elsewhere), the embryo sac started to increase its size and changed its morphology, thus at five DAP, the embryo sac had increased its size to about $280 \mu \mathrm{m}$ long and $125 \mu \mathrm{m}$ wide. At the same time, the embryo sac walls near the chalazal end and those that surround the haustorial tube begin to move towards the nucellar tissue (Figure 6a).

The zygote formation could be observed as the result of the fertilization of the egg cell by one of two sperm nuclei. The zygote possessed a hemispherical shape of $40 \mu \mathrm{m}$ long and $38 \mu \mathrm{m}$ wide, and a well polarized nucleus towards the chalazal pole of the embryo sac (Figure 6a). At the same time of zygote formation, the formation of disperse cells of the endosperm could be observed (Figure 6a,b, c). The endosperm of Agave tequilana was of the helobial type. The first mitotic division of the primary endosperm nucleus forms a cell wall, which generates two cells: a small cell at the chalazal extreme and a large cell at the micropylar extreme that occupies most of the embryo sac (see Additional file 2: Figure S4).

\section{Zygotic development and post-fertilization changes of the embryo sac}

At six DAP, the Agave tequilana zygote enlarges almost $50 \%$ maintaining its original width. Meanwhile, the endosperm nuclei continued dividing and were mainly located at the central and chalazal regions of the embryo sac. Several nuclear divisions of the endosperm could be observed 

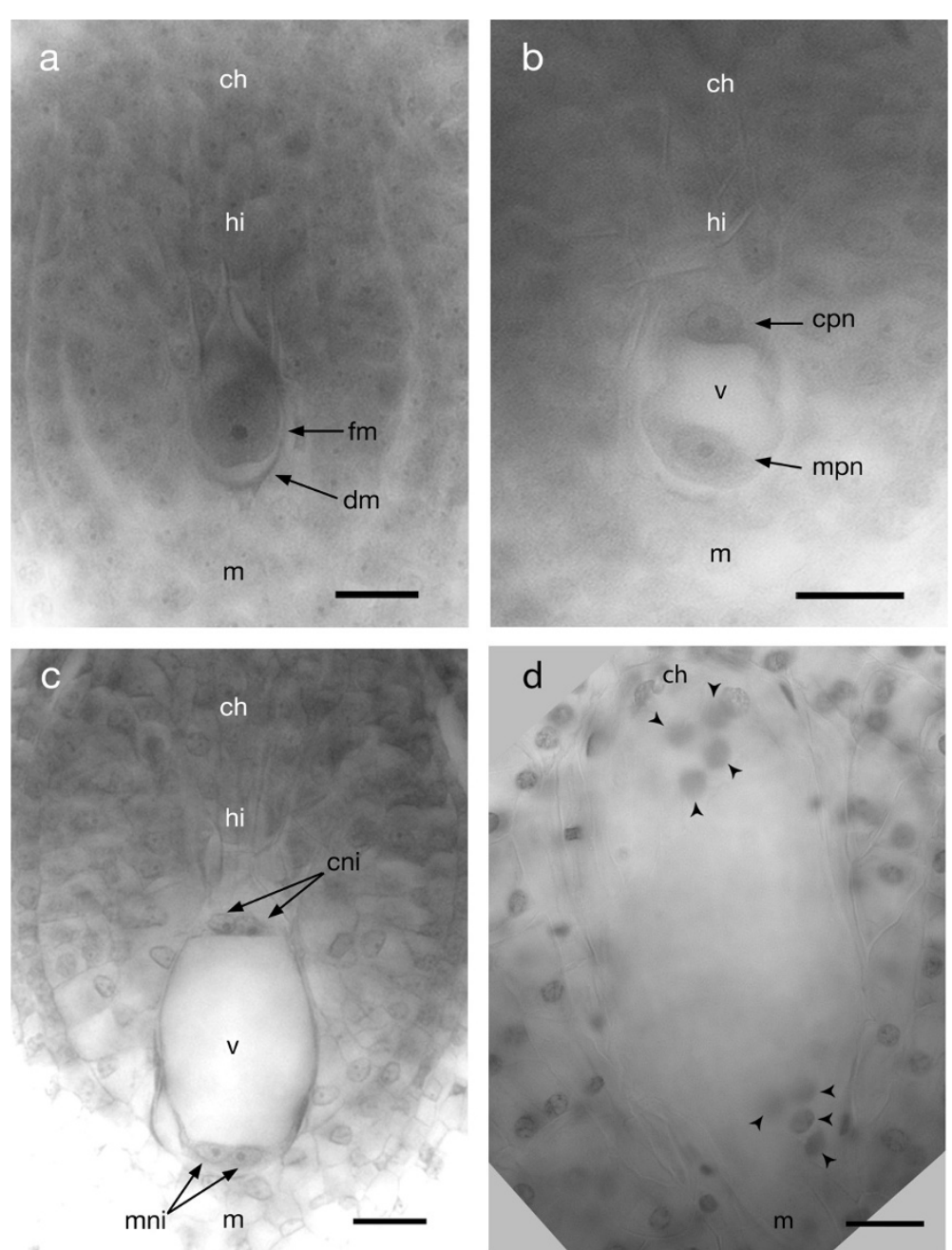

Figure 3 Megagametogenesis of Agave tequilana Weber. a) Functional megaspore with the rest of the degenerated megaspores. Bar $=20 \mu \mathrm{m}$. b) Two nuclei resulting after a first mitotic division of the functional megaspore. Bar $=20 \mu \mathrm{m}$. c) Four-nuclei state after a second mitotic division. Bar $=20 \mu \mathrm{m}$. d) Eight-nuclei state forming a multinucleate coenocyte after the third and last mitotic division. Bar $=20 \mu \mathrm{m}$. ch $=c$ chalaza, hi $=$ hypostase, $\mathrm{m}=$ micropyle, $\mathrm{fm}=$ functional megaspore $\mathrm{dm}=$ degenerating megaspores, $\mathrm{cpn}=$ chalazal polar nucleus, $\mathrm{mpn}=$ micropylar polar nucleus, $\mathrm{cni}=\mathrm{chalazal}$ nuclei, $\mathrm{mni}=$ micropylar nuclei. Arrowheads = eight final nuclei.

before the first division of the zygote occurred. Likewise, the embryo sac changes in form and size radically, its shape is irregular and resembles that of a heart, the walls surrounding the haustorial chalazal tube still pushing towards the chalaza thus forming two haustoria: a new one on each side of the chalazal end of the sac divided by a remnant of tissue called "postament" which in turn included the hypostase which was connected to the former chalazal haustorium (Figure 6b). Similarly, at the micropylar extreme starts the formation of the micropylar haustorium where the zygotic embryo is developed (Figure $6 c, d$, e). At this stage of development, it was possible to observe well defined chambers, one at the micropylar end and two at the chalazal end (Figure 6e).

At eight and nine DAP the first division of the zygote could be observed. This first division gives rise to two cells: one basal cell and one apical cell that would form the embryo proper. Similarly to the zygote nucleus, the embryo apical cell showed a high polarity directed to the chalazal extreme. This polarity that is preserved from the egg cell, resulted in the asymmetric division of the zygote, thus the apical cell was smaller than the basal cell, and possessed a big and well-defined nucleus, while the basal cell seemed to be highly vacuolated (Figure 6d). At this point, the fertilized embryo sac is an immature seed ready toward maturity (Figure 6f).

\section{Discussion}

\section{Megasporogenesis}

The chalaza-micropyle linear orientation of tetrads in other species of this family has been previously reported in Yucca rupicola (Watkins 1937) and Agave lechuguilla 

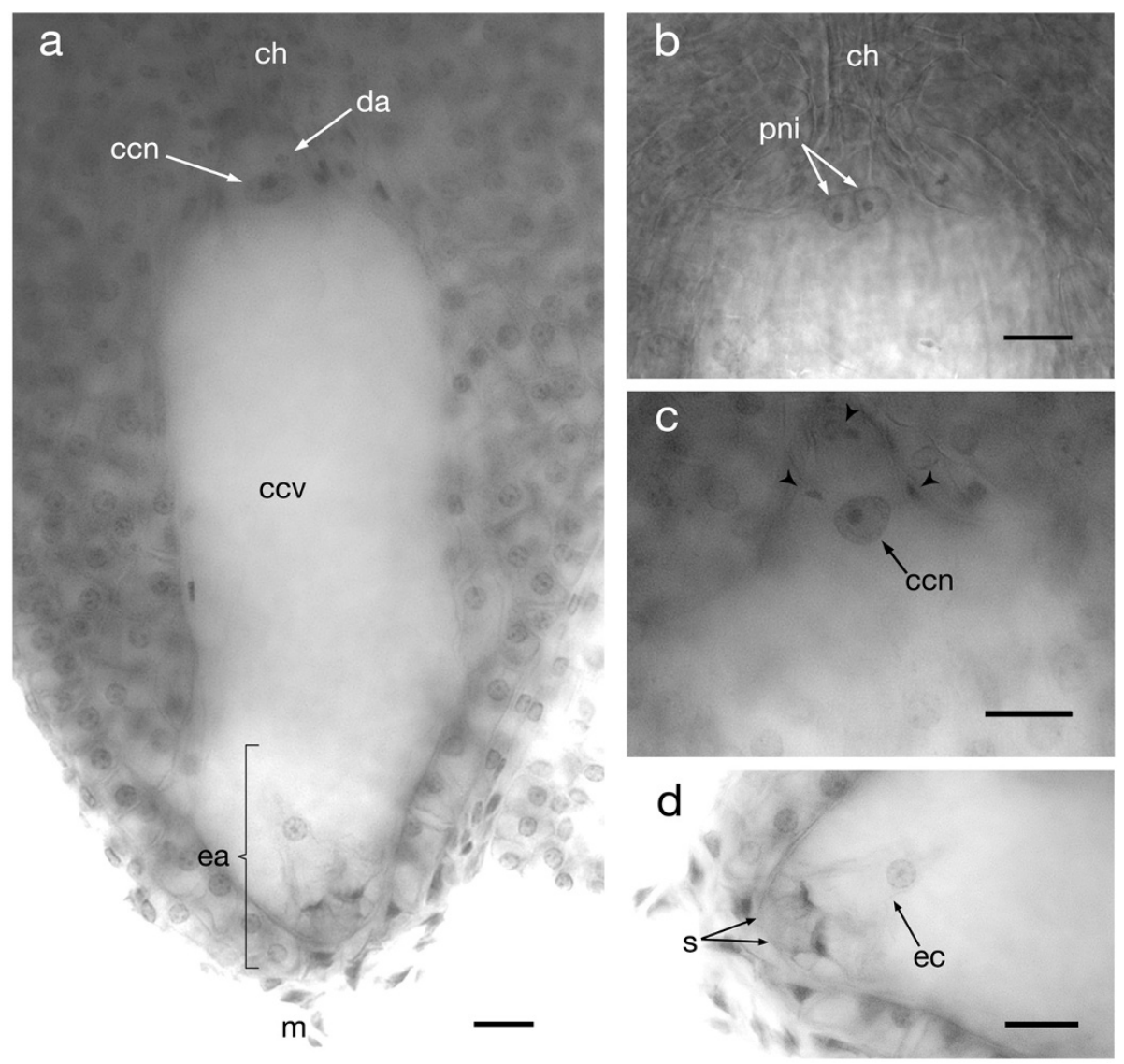

Figure 4 Mature embryo sac or megagametophyte of Agave tequilana Weber. a) Whole mature embryo sac showing the contents of both the chalazal and the micropylar poles. b) Polar nuclei at the chalazal end before karyogamy. c) Central cell nucleus after karyogamy took place. d) Egg apparatus composed by two synergid cells and the egg cell. ch = chalaza, ea =egg apparatus, $m=$ micropyle, da = degenerating antipodal cell, $c c n=$ central cell nucleus, $c c v=$ central cell vacuole, $p n i=$ polar nuclei, $s=$ synergid cells, ec =egg cell. Arrowheads = degenerating antipodal cells. Bars $=20 \mu \mathrm{m}$.

(Grove 1941). However, Wolf (1940) reported the "T" formation of tetrads as the most frequent arrangement in Y. aloifolia, while Regen (1941) and Cave (1948) reported that the formation of meiotic tetrads may take either the " $\mathrm{T}$ " or the linear shape in A. virginica and Hesperocallis undulata respectively.

In Agave tequilana, only the closest megaspore cell to the chalazal pole remains viable (Monosporic-type) becoming the functional megaspore (FM). This is the case of most angiosperms including Arabidopsis thaliana and Zea mays (Yang et al. 2010) and the close related species Agave virginica (Regen 1941) and Yucca aloifolia (Wolf 1940). However, this megaspore is not always the one that survives, Reed (1903) reported that is the second closest megaspore the one that remains viable and is converted to a FM in Y. filamentosa. On the other hand, Piven et al. (2001) observed that the embryo sac of Agave fourcroydes and $A$. angustifolia develops from the two megaspores closest to the micropylar pole originating an embryo sac of the bisporic Allium-type.

\section{Megagametogenesis}

The size of the functional megaspore $(43 \mu \mathrm{m}$ long and $25 \mu \mathrm{m}$ wide) found in the present study was similar to the dimensions reported for Tofieldia glutinosa where the size of the FM was 35-50 $\mu \mathrm{m}$ long and $12-20 \mu \mathrm{m}$ wide (Holloway and Friedman 2008). The hypostase located at the chalazal pole of the embryo sac in the nucellar tissue is reported as frequent among members of the Asparagaceae (formerly Agavaceae) family (Tilton and Mogensen 1980), and it is probable that it plays an important function in the translocation of nutrients from the ovule to the gametophyte before and after fertilization (Tilton 1980). Furthermore, the three synchronized mitotic divisions without cytokinesis of the functional megaspore were similar to many reported in 


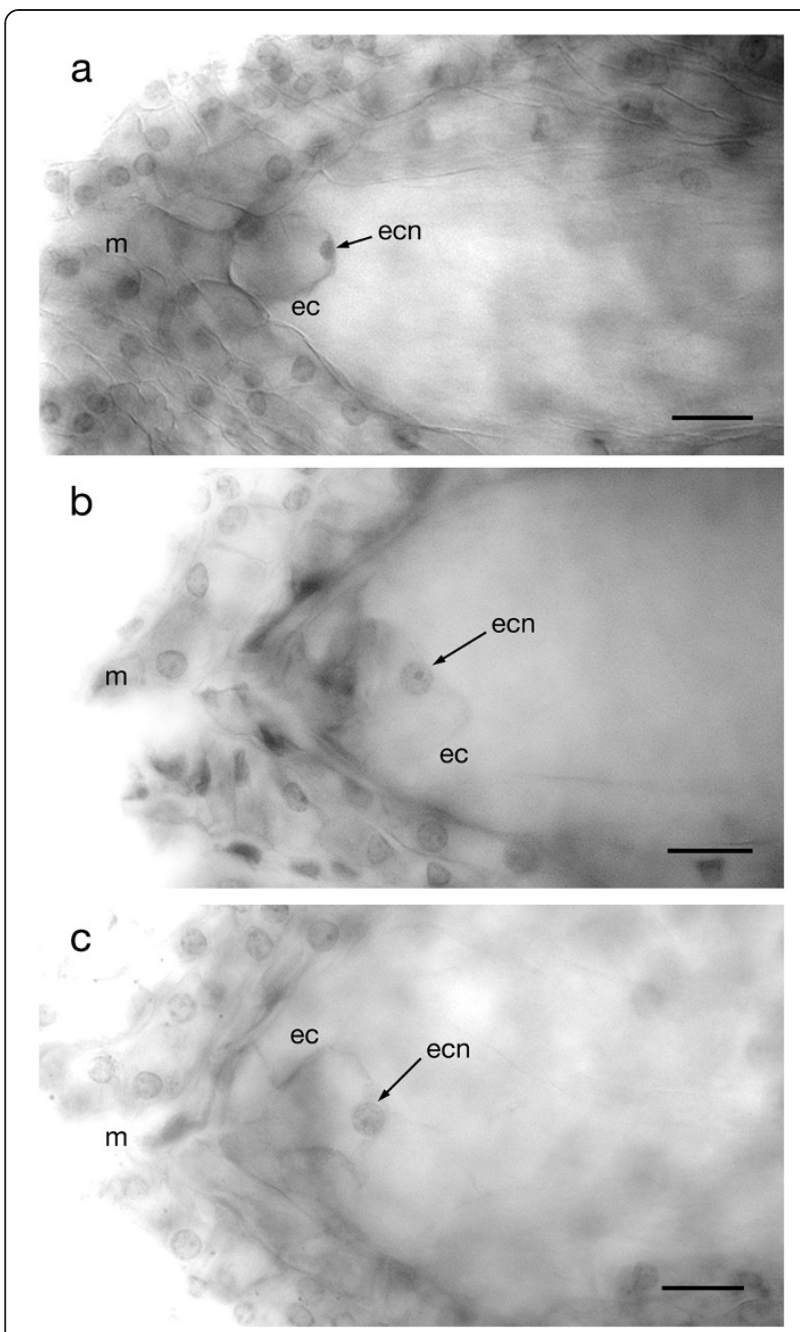

Figure 5 Different egg cell shapes of Agave tequilana Weber. a) Typical ovoid-shaped egg cell showing a highly condensed nucleus located at the chalazal end of the embryo sac. b) and c) Egg cells of an irregular shape with nucleus located at the chalazal end of the embryo sac. $m=$ micropyle, ec $=$ egg cell, ecn = egg cell nucleus. Bars $=20 \mu \mathrm{m}$.

the literature i.e. in the formation of the maize embryo sac (Huang and Sheridan 1994).

\section{The mature embryo sac}

The haustorial tube at the chalazal end of the embryo sac observed in Agave tequilana resembles to that reported by Tilton (1978) for Ornithogalum. This haustorial tube may play a role for some kind of a nutritious function and penetrates the nucellar tissue close to the hypostase and the vascular strands, which come from the funiculus (Reed 1903; Watkins 1937; Wolf 1940; Rudall 1997).

The cellularized embryo sac consisted of seven cells (eight nuclei): three antipodal cells situated at the chalazal end (only their residues could be observed); two polar nuclei close to the antipodals and the egg apparatus containing one egg cell and two synergids. Occasionally, sacs with less than eight nuclei are found in many species and this can be due to a rapid degeneration of the antipodals or they may go unnoticed because they are hidden at the end of the chalazal tube (Maheshwari 1948, 1950). This phenomenon of rapid disintegration of the antipodal cells has been reported for several plant species, such as Agave virginica (Regen 1941), Glycine max (Kennell and Horner 1985), Scilla persica (Svoma and Greilhuber 1988), Triticum aestivum (Zhang et al. 1988; An and You 2004), Arabidopsis thaliana (Murguia et al. 1993), Passiflora edulis (Magalhães de Souza et al. 2002), Sargentodoxa cuneata (Wang et al. 2009) and Cichorium intybus (Chehregani et al. 2011).

According to Tilton (1978), in angiosperms, antipodals are cells that vary in their behavior in the mature megagametophyte and the only trait they share with each other is their location in the chalazal end of the sac; the antipodals can be ephemeral, degraded shortly after their formation or persist even after fertilization (Williams and Friedman 2004). In Tofieldia glutinosa, antipodals can even proliferate in the maturation stage of the embryo sac, being up to eight antipodal nuclei (Holloway and Friedman 2008). Polar nuclei in Agave tequilana were observed close to the antipodals remains and being similar in shape and size as reported by Maheshwari (1950) and Tilton and Lersten (1981). The position of the polar nuclei is similar to that observed in Hemiphylacus alatostylus (Rudall et al. 1997) which are located in the chalazal end within a tube or neck (chalazal haustorium), and in Tofieldia glutinosa where polar nuclei are located at a two-thirds distance from the micropylar end of the embryo sac (Holloway and Friedman 2008).

Moreover, the close contact of the egg apparatus with the micropyle is highly similar to what was observed in the ovular apparatus of Ornithogalum caudatum (Tilton 1978), and the polarization of the nucleus of both synergids towards the micropylar end was similar to what was reported for tobacco (Tian et al. 2005). Furthermore, as in many other angiosperms, the egg cell possesses a highly dense nucleus located towards the chalazal extreme of the embryo sac (Tilton 1978; Mogensen and Suthar 1979; Tian et al. 2005).

\section{The central cell: karyogamy of the polar nuclei}

It was observed that in Agave tequilana, karyogamy of the polar nuclei to form the diploid nucleus of the central cell occurred before the process of double fertilization, similar to that observed in ovules of Capsella bursa-pastoris (Schulz 1973) and Tofieldia glutinosa (Holloway and Friedman 2008). This diploid nucleus remained at the same place where both polar nuclei were observed at the chalazal extreme of the embryo sac. This chalazal position of the central cell nucleus has been observed in 

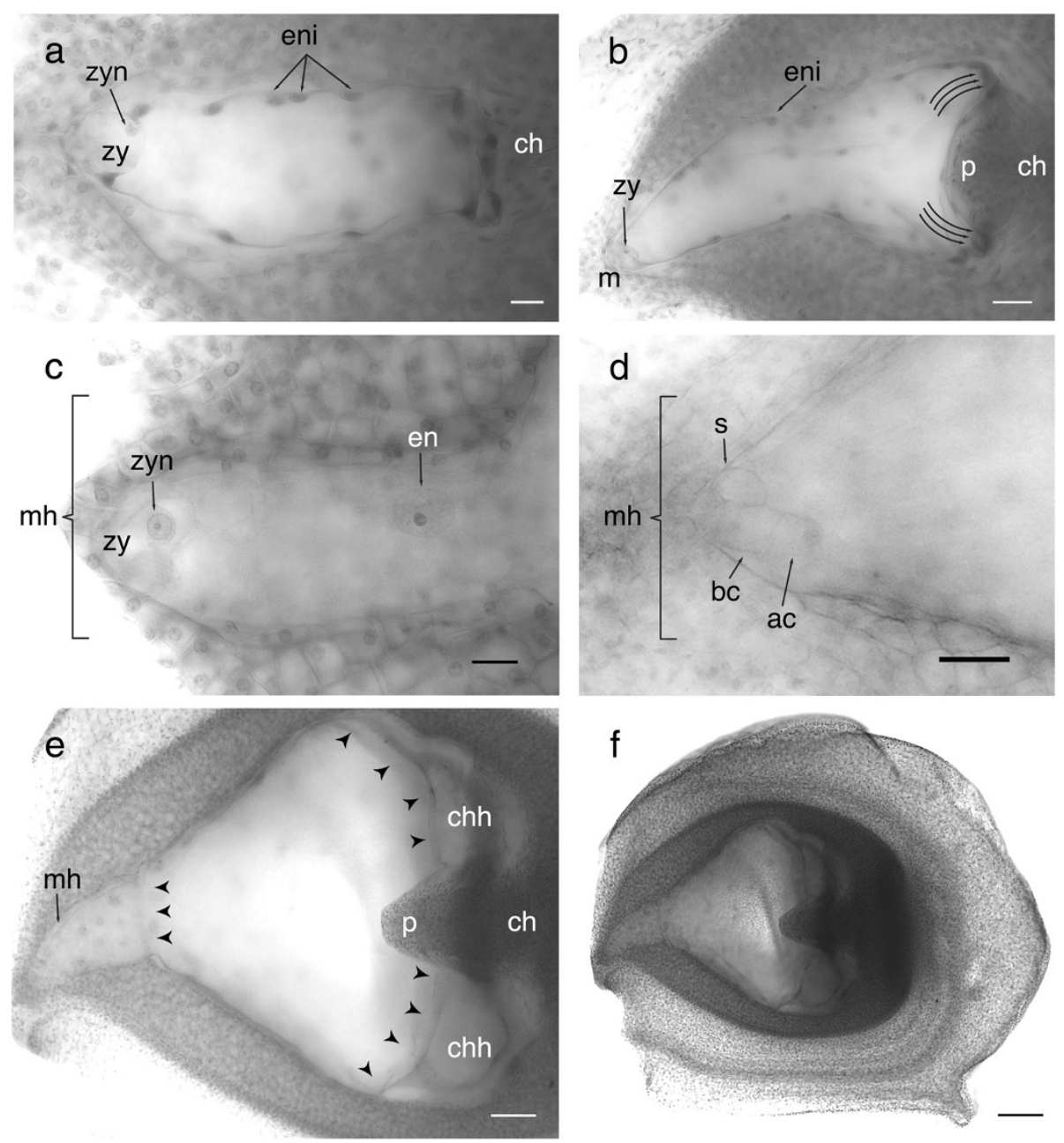

Figure 6 Early embryo development of Agave tequilana Weber. a) Zygote and early endosperm development. Bar $=10 \mu \mathrm{m}$. b) Formation of the chalazal haustorium (curved arrows) Bar $=50 \mu \mathrm{m}$. c) Formation of the micropylar haustorium. Bar $=25 \mu \mathrm{m}$. d) First division of the zygote showing the apical and basal cells of the early embryo. Bar $=25 \mu \mathrm{m}$. e) and $\mathbf{f}$ ) Immature seed showing the micropylar haustorium and the chalazal haustorium including the postament. Bar in $e=100 \mu \mathrm{m}$ and Bar in $\mathrm{f}=200 \mu \mathrm{m}$. ch = chalaza, $\mathrm{m}=$ micropyle, zy $=$ zygote, zyn $=$ zygote nucleus, eni = endosperm nuclei, $\mathrm{p}=$ postament, $\mathrm{mh}=$ micropylar haustorium, chh = chalazal haustorium, en = endosperm nucleus, $\mathrm{s}=$ synergid, $\mathrm{bc}=$ basal cell, $\mathrm{ac}=$ apical cell. Curved arrows = haustoria pushing towards the chalaza, arrowheads = endosperm chambers. (for more detail, see close-up in Additional file 2: Figure S5).

Yucca rupicola (Watkins 1937), Persea americana (Tomer and Gottreich 1976) and Tofieldia glutinosa (Holloway and Friedman 2008) among others. However, Piven et al. (2001) reported for Agave fourcroydes and A. angustifolia that the position of the polar nuclei and finally the nucleus of the central cell were located in the center of the embryo sac; or close to the egg apparatus at the micropylar end, a pattern that is present in almost all angiosperms (Tilton 1978; Russell 1993), particularly in Zea mays (Huang and Sheridan 1994) and in Arabidopsis thaliana (Olsen 2004).

\section{Endosperm and zygote formation}

Double fertilization gives rise to both, the zygote and the endosperm. In this work the typical polarization of the zygote nucleus towards the chalazal pole could be observed. This polarization of the zygote nucleus resembled those of Capsella bursa-pastoris (Schulz and Jensen 1968), Nicotania tabacum (Mogensen and Suthar 1979) and Arabidopsis thaliana (Mansfield and Briarty 1991; Mansfield et al. 1991).

In this study, the helobial type of endosperm development was similar to the one reported for Hesperocallis undulata (Cave 1948) which has the central cell nucleus at the chalazal extreme of the embryo sac just below of the antipodal cell remains located at the chalazal tube. Maheshwari (1950) reported that when the position of the central cell nucleus is located close to the antipodals, the endosperm type of development will be helobial. 


\section{Zygotic development and changes post-fertilization in the embryo sac}

At six DAP, the Agave tequilana zygote enlarged almost $50 \%$ maintaining its original shape, this enlargement has been previously reported for Arabidopsis thaliana (Bowman et al. 1994) among many others, and the endosperm cells continued dividing before the first division of the zygote. These observations are similar to those in Amaranthus hypochondriacus (Coimbra and Salema 1999), suggesting that the central cell is precocious in regard to its development after fertilization. Around these days, the embryo sac suffers drastic changes in size and with the formation of the micropylar haustorium where the zygote is located and with the formation of two chalazal haustoria. There exist several reports about the formation of chalazal haustoria in species belonging to the Asparagales, where the endosperm development invades lateral sections of the proximal nucellus, destroying the lateral tissue and leaving the "postament" at the center of the sac (Rudall 1997).

Finally, at nine DAP the first division of the zygote takes place giving rise to one basal cell and one apical cell which is the first cell of the embryo proper. This observed process was similar to what is described for the majority of angiosperms (Lau et al. 2012). Furthermore, the polarity of the embryo apical cell toward the chalazal extreme of the embryo sac occurred similarly as in most of flowering plants (Rodríguez-Garay et al. 2000).

\section{Conclusions}

The Agave tequilana embryo sac development is a monosporic Polygonum-type, showing ephemeral antipodals. In the present work, the detailed embryo sac development, the formation of the zygote, the early embryo formation and the helobial type of endosperm are reported for the first time in this species. However, further ultrastructural studies are needed for a more detailed knowledge. The results reported here show basic knowledge about the early embryo development and allow new paths for basic and applied research for systematic and evolutionary studies and breeding programmes where in vitro fertilization, selfing, and intraand inter-generic hybridization are needed.

\section{Methods}

Agave tequilana presents perfect flowers with six tepals and anthers, an inferior ovary that is divided in three locules, each locule containing two rows of numerous anatropous ovules with axillary placentation (Gentry 1982). The plant material used in this study consisted of inflorescences collected from mature plants growing in the state of Jalisco, which is located in the Tequila appellation of origin in Mexico (DOF 1977), from May to June in the years 2010-2013.

At the beginning of the flowering season, panicles that contained flower buds with different development stages were collected (five panicles per inflorescence or plant). Afterwards, ovules from these young buds were extracted from the ovary using fine forceps and knives under a dissection microscope, and then fixed in a FAA solution (10:5:50:35 formaldehyde: acetic acid: ethanol; distilled water) for 24 hours. After fixation, ovules were transferred to a $70 \%$ ethanol solution and stored at $5^{\circ} \mathrm{C}$ for later staining.

In order to maintain cross-pollination to ensure fertilization and embryo formation, the rest of the flower buds were emasculated before anthesis and removed anthers were kept at room temperature until they matured after one or two days. Mature pollen was recovered and stored in a desiccator at $4^{\circ} \mathrm{C}$ for future pollinations. Once stigmas were receptive, 10 mature non-pollinated flowers were selected per each panicle and their ovules were extracted from the ovaries, they were processed following the procedure used for buds. The rest of the flowers with receptive stigmas were hand pollinated using a small paintbrush. Crosspollination was carried out since auto-pollination did not assure fertilization. In order to study the embryo sac and zygotic embryo development, 10 immature fruits were collected from panicles at 2, 3, 4, 5, 6, 8 and 9 days after pollination (DAP).

Ovules and immature seeds, previously fixed in FAA and kept in $70 \%$ ethanol, were stained based on the technique reported by Stelly et al. (1984), in short, a Mayer's-Hematoxylin solution was used for staining during a 10-24-hour period and then treated with a $2 \%$ acetic acid solution during a 16-hour period in order to eliminate the excess stain. Ovule samples were washed with a $0.1 \%$ sodium bicarbonate solution until the solution was clear. At this point, ovules were left in the same $0.1 \%$ sodium bicarbonate solution for 24 hours at room temperature before dehydration. Afterwards, samples were dehydrated in an ethanol series of $25 \%, 50 \%$, $70 \%, 85 \%, 95 \%$ and $100 \%$ during 15 minutes, and finally, in $100 \%$ ethanol during 2 hours. Clarification was carried out through a series of methyl salicylate:ethanol solutions of 3:1, 1:1, 1:3, for one hour each.

Clarified ovules were mounted in a methyl salicylate solution for microscope observation. The samples were analyzed using a Leica DMR microscope (Wetzlar, Germany) coupled to an Evolution QEi camera (MediaCybernetics, Bethesda, USA). Images were taken using Image $\mathrm{Pro}^{\circ}$ software (Media-Cybernetics, Bethesda, USA), and microphotographs were processed with the Adobe Photoshop Software version CS6 and evenly adjusted for better contrast. 


\section{Additional files}

Additional file 1: Table S1. Mean size of the different developmental stages in the analized ovules of Agave tequilana.

Additional file 2: Figure S1. Structure of the ovule of Agave tequilana. Figure S2. The antipodal cells and the central cell nucleus of Agave tequilana. Figure S3. The synergid cells of Agave tequilana. Figure S4. Helobial endosperm development in Agave tequilana. Figure S5. Close-up of a two celled embryo of Agave tequilana showing a large vacuolated basal cell.

\section{Competing interests}

The authors declare that they have no competing interests.

\section{Authors' contributions}

AGGG carried out the microscope analyses, the acquisition of data, the analysis and interpretation of data and drafted the manuscript. AGM helped with interpretation of data and revised the manuscript. BRG conceived and coordinated the study, carried out analysis and interpretation of data and drafted the manuscript. All authors read and approved the final manuscript.

\section{Acknowledgements}

We thank V.M. Gómez-Rodríguez and J. M. Rodríguez-Domínguez for microscope technical assistance and I.J. Román-Guzmán, F.J. CervantesHernández and $\mathrm{H}$. Rodríguez-Julián for their assistance with the artwork. We also thank C. Vélez-Gutiérrez (Tequila Cuervo, S.A. de C.V.) for providing Figure 1a. A.G.G.G. is currently a graduate student at Posgrado en Ciencias de la Floricultura, CIATEJ, Guadalajara, Jalisco, México. This work was supported (to B.R.G.) by Consejo Nacional de Ciencia y Tecnología, México (CB-24554) and Sistema Nacional de Recursos Fitogenéticos para la Alimentación y la Agricultura-Servicio Nacional de Inspección y Certificación de Semillas, México (BEI-AGA-10-8, BEI-AGA-11-8).

Received: 20 July 2014 Accepted: 24 September 2014 Published: 1 October 2014

\section{References}

An LH, You RL (2004) Studies on nuclear degeneration during programmed cell death of synergid and antipodal cells in Triticum aestivum. Sex Plant Reprod 17:195-201

Angiosperm Phylogeny Group (APG III) (2009) An update of the Angiosperm Phylogeny Group classification for the orders and families of flowering plants. Bot J Linn Soc 161:105-121

Bowman JL, Mansfield SG, Koorneef M (1994) Embryogenesis. In: Bowman JL (ed) Arabidopsis, an atlas of morphology and development, 1st edn. SpringerVerlag, New York, pp 349-401

Cave MS (1948) Sporogenesis and embryo sac development of Hesperocallis and Leucocrinum in relation to their systematic position. Am J Bot 35:343-349

Chasan R, Walbot V (1993) Mechanisms of plant reproduction: questions and approaches. Plant Cell 5:1139-1146

Chehregani A, Mohsenzade F, Ghanad M (2011) Male and female gametophyte development in Cichorium intybus. Int J Agr Biol 13:603-606

Coimbra S, Salema R (1999) Ultrastructure of the developing and fertilized embryo sac of Amaranthus hypochondriacus L. Ann Bot 84:781-789

Diario Oficial de la Federación (DOF) (1977) Declaración General de Protección de a la Denominación de Origen "Tequila". October 13, 1977, México, DF

Dresselhaus T (2006) Cell-cell communication during double fertilization. Curr Opin Plant Biol 9:41-47

Escobar-Guzmán RE, Zamudio-Hernández F, Gil-Vega K, Simpson J (2008) Seed production and gametophyte formation in Agave tequilana and Agave americana. Botany 86:1343-1353

Fan YF, Jiang L, Gong HQ, Liu CM (2008) Sexual reproduction in higher plants I: fertilization and the initiation of zygotic program. J Integr Plant Biol 50:860-867

Gentry HS (1982) Agaves of continental North America. The University of Arizona Press, Tucson, Arizona

Grove AR (1941) Morphological study of Agave lechuquilla. Bot Gaz 103:354-365

Gutiérrez-Mora A, González-Gutiérrez AG, Rodríguez-Garay B, Ascencio-Cabral A, Li-Wei L (2012) Plant somatic embryogenesis: some useful considerations. In: Sato KI (ed) Embryogenesis. InTech, Rijeka, pp 229-241
Haig D (1990) New perspectives on the angiosperm female gametophyte. Bot Rev 56:236-274

Holloway SJ, Friedman WE (2008) Embriological features of Tofieldia glutinosa and their bearing on the early diversification of monocotyledonous plants. Ann Bot 102:167-182

Huang BQ, Sheridan WF (1994) Female gamethophyte development in maize: microtubular organization and embryo sac polarity. Plant Cell 6:845-861

Kägi C, Groß-Hardt R (2007) How females become complex: cell diffentiation in the gametophyte. Curr Opin Plant Biol 10:633-638

Kennell JC, Horner HT (1985) Megasporogenesis and megagametogenesis in soybean, Glycine max. Am J Bot 72:1553-1564

Lau S, Slane D, Herud O, Kong J, Jürgens G (2012) Early embryogenesis in flowering plants: setting up the basic body pattern. Annu Rev Plant Biol 63:483-506

Li W, Ma H (2002) Gametophyte development. Curr Biol 12:R718-R721

Ma H, Sundaresan V (2010) Development of flowering plant gametophytes. Curr Top Dev Biol 91:379-412

Magalhães de Souza M, Santana-Pereira T, Hoffmann M, de Melo EJT, PereiraLouro R (2002) Embryo sac development in yellow passion fruit Passiflora edulis f. flavicarpa (Passifloraceae). Genet Mol Biol 25:471-475

Maheshwari P (1937) A critical review of the types of embryo sacs in angiosperms. New Phytol 36:359-417

Maheshwari P (1948) The angiosperm embryo sac. Bot Rev 14:1-56

Maheshwari P (1950) An introduction to the embryology of angiosperms. McGraw-Hill, New York

Mansfield SG, Briarty LG (1991) Early embryogenesis in Arabidopsis thaliana. II. The developing embryo. Can J Bot 69:461-476

Mansfield SG, Briarty LG, Erni S (1991) Early embryogenesis in Arabidopsis thaliana. I. The mature embryo sac. Can J Bot 69:447-460

Mogensen HL, Suthar HK (1979) Ultrastructure of the egg apparatus of Nicotiana tabacum (Solanaceae) before and after fertilization. Bot Gaz 140:168-179

Murguia M, Huang BQ, Tucker SC, Musgrave ME (1993) Embryo sac lacking antipodal cells in Arabidopsis thaliana (Brassicaceae). Am J Bot 80:824-838

Olsen OA (2004) Nuclear endosperm development in cereals and Arabidopsis thaliana. Plant Cell 16:S214-S227

Piven NM, Barredo-Pool F, Borges-Argáez IC, Herrera-Alamillo MA, MayoMosqueda A, Herrera-Herrera JL, Robert ML (2001) Reproductive biology of henequén (Agave fourcroydes) and its wild antecessor Agave angustifolia (Agavaceae). I gametophyte development. Am J Bot 88:1966-1976

Rabiger DS, Drews GN (2013) MYB64 and MYB119 are required for cellularization and differentiation during female gametogenesis in Arabidopsis thaliana. PLOS Genet 9:e1003783

Reed HS (1903) The development of the macrosporangium of Yucca filamentosa. Bot Gaz 35:209-214

Regen $L$ (1941) The development of the embryo sac in Agave virginica. Bull Torrey Bot Club 68:229-236

Reiser L, Fischer RL (1993) The ovule and the embryo sac. Plant Cell 5:1291-1301

Rodríguez-Garay B, Santacruz-Ruvalcaba F, Loera-Quezada MM, Gutiérrez-Mora A (2000) Embriogénesis sexual y somática en plantas. Hort Mex 8:104-113

Rudall PJ (1997) The nucellus and chalaza in monocotyledons: structure and systematics. Bot Rev 63:140-181

Rudall PJ (1999) Flower anatomy and systematics of Comospermum (Asparagales). Syst Geogr Plant 68:195-202

Rudall PJ, Engleman EM, Hanson L, Chase MW (1997) Embryology, cytology and systematics of Hemiphylacus, Asparagus and Anemarrhena (Asparagales). Plant Syst Evol 211:181-199

Russell SD (1993) The egg cell: development and role in fertilization and early embryogenesis. Plant Cell 5:1349-1359

Schulz P (1973) Capsella embryogenesis: the central cell. J Cell Sci 12:741-763

Schulz R, Jensen WA (1968) Capsella embryogenesis: the egg, zygote and young embryo. Am J Bot 55:07-19

Stelly DM, Peloquin SJ, Palmer RG, Crane CF (1984) Mayer's hemalum-methyl salicylate: a stain-clearing technique for observations within whole ovules. Biotech Histochem 59:155-161

Svoma E, Greilhuber J (1988) Studies on systematic embryology in Scilla (Hyanthaceae). Plant Syst Evol 161:169-181

Tian HQ, Yuan T, Russell SD (2005) Relationship between double fertilization and the cell cycle in male and female gametes of tobacco. Sex Plant Rep 17:243-252

Tilton VR (1978) A developmental and histochemical study of the female reproductive system in Ornithogalum caudatum Ait. using and electron microscopy. PhD Dissertation, lowa State University, Ames, lowa 
Tilton VR (1980) Hypostase development in Ornithogalum caudatum (Liliaceae) and notes on other types of modifications in the chalaza of angiosperm ovules. Can J Bot 58:2059-2066

Tilton VR, Lersten NR (1981) Ovule development in Ornithogalum caudatum (Liliaceae) with a review of selected papers on angiosperm reproduction. III. Nucellus and megagametophyte. New Phytol 88:477-504

Tilton VR, Mogensen HL (1980) Ultrastructural aspects of the ovule of Agave parryi before fertilization. Phytomorphology 29:338-350

Tomer E, Gottreich YM (1976) Defective ovules in avocado cultivars. J Am Soc Hortic Sci 101:620-623

Wang HF, Kirchoff BK, Qin HN, Zhu ZX (2009) Reproductive morphology of Sargentodoxa cuneata (Lardizabalaceae) and its systematic implications. Plant Syst Evol 280:207-217

Watkins GM (1937) Embryo-sac development in Yucca rupicola. Am J Bot 24:481-484

Williams JH, Friedman WE (2004) The four-celled female gametophyte of Illicium (Illiciaceae; Austrobaileyales): implications for understanding the origin and early evolution of monocots, eumagnoliids, and eudicots. Am J Bot 91:332-351

Wolf FT (1940) Macrosporogenesis and the development of the embryo sac in Yucca aloifolia. Bull Torrey Bot Club 67:755-761

Yadegari R, Drews GN (2004) Female gametophyte development. Plant Cell 16:S133-S141

Yang WC, Shi DQ, Chen YH (2010) Female gametophyte development in flowering plants. Annu Rev Plant Biol 61:89-108

Zhang WC, Yan WM, Lou CH (1988) The structural changes during the degeneration process of antipodal complex and its function to endosperm formation in wheat caryopsis. Acta Bot Sin 30:457-462

doi:10.1186/2193-1801-3-575

Cite this article as: González-Gutiérrez et al:: Embryo sac formation and early embryo development in Agave tequilana (Asparagaceae).

SpringerPlus 2014 3:575

\section{Submit your manuscript to a SpringerOpen ${ }^{\circ}$ journal and benefit from:}

- Convenient online submission

- Rigorous peer review

- Immediate publication on acceptance

Open access: articles freely available online

- High visibility within the field

- Retaining the copyright to your article

Submit your next manuscript at $>$ springeropen.com 